\title{
The Moderating Effect of Location on Small Firm Performance:
}

\section{Empirical Evidence}

\author{
Mohd Sobri Minai \\ College of Business, Universiti Utara Malaysia, Malaysia \\ Esuh Ossai-Igwe Lucky \\ College of Business, Universiti Utara Malaysia, Malaysia \\ Tel: 60-10-461-7732 E-mail: igwedegreat@yahoo.com
}

Received: April 27, 2011 Accepted: May 18, $2011 \quad$ Published: October 1, 2011

doi:10.5539/ijbm.v6n10p178 URL: http://dx.doi.org/10.5539/ijbm.v6n10p178

\begin{abstract}
The global interest on entrepreneurship and small business development as a means of economic sustainability and growth through emphasis on location has not been commonly utilized and openly declared. However, the inconsistent results on the relationship between entrepreneurial factors and firm performance have led the authors to propose a contingency model in which the effects of individual determinants, external factors and firm characteristics on firm performance are moderated by location. A cross-sectional study of questionnaire survey research design was conducted and data was generated from 182 entrepreneurs or owner-managers of small firms in both manufacturing and service industries. The questionnaires were distributed through drop-off and pick procedure of data collection. The findings indicate that location strongly moderate the relationship between both external factors and firm characteristics with firm performance. However, it is found that location factor does not moderate the relationship between individual determinant and small firm performance.
\end{abstract}

Keywords: Entrepreneurship determinants, Location, Entrepreneurship development

\section{Introduction}

The constant examination on entrepreneurship development is almost becoming a routing exercise by many researchers in various countries (Greening, Barringer and Macy, 1996; Rebecca and Benjamin 2009; Rajesh, 2006). For instance, in India, Rajesh (2006) reported that India government is mobilizing a large population of capable of entrepreneurial activities. In Nigerian, Arowomole, (2000) asserted that every successive governemnt continue to emphasis on entrepreneurship development. This is probably to find a better way of nurturing the entrepreneurship development by looking for those entrepreneurial factors such as location that could effectively and positively affect the entrepreneurial development as well as that of the firm performance.

With reference to above, many past studies have documented the significant impact of entrepreneurial factors such as individual determinants, external factors and firm characteristics on entrepreneurial performance. For instance, Hashim (2005); Blackman (2003); Ogundele (2007); Colin et al., (2005) and Lawal (2005) argued that individual determinant which is also called entrepreneurial characteristics significantly and positively affect both entrepreneurial development and entrepreneurial performance. Similarly, Van de ven (1993); Hashim (2005); Arowomole (2000); Kuratko et al., (2004) and (Radiah, Mohd and Ab, 2009) have asserted that external factors predict and significantly affect entrepreneurial performance as well as entrepreneurship develoment of any country. With respect to this, Van de van(1993) has further argued that any study within the field of entrepreneurship development without the consideration of external factors which he nicknamed external environement should be considered incomplete and invalide. Accordingly, Johan et al., (2005); Hashim (2005); Lim (2006) and Dean et al., (2000) argued that firm characteristcis such as firm size, nature of firm etc affect the performance of the firm.

From the above, there is no doubt that past studies have really given attention to the impact of individual determinants, external factors and firm characteristics on firm performance (Rebecca et al., 2009; Willian, 2009; 
Zhang et al., 2008; Okpara et al., 2007; Ogundele, 2007). Despite this attention extended to these factors, Man, Lau and Chan, (2002) have argued that all these factors reference in this study still deserve further attention in the study of entrepreneurship and small business. However, while different factors such as individual determinants, external factors and firm characteristics have been found to influence entrepreneurial performance to different extents, the results are often inconsistent (Man et al., 2002, Yanfeng and Si, 2008, 2008; Kisfalvi, 2002; Dean et al., 2000; Pelham, 1999; (Chandler and Hanks, 1994; Cooper, 1993). In order to tackle this problem, past studies have suggested contingency relationships on different conditions and interactions (Fanga, Evans and Zou, 2005; Man et al., 2002), in line with this, this study therefore, proposes a contingency model in which the effects of individual determinants, external factors and firm characteristics on firm performance are moderated by location.

Furthermore, while there are also substantial researches on the moderating effect of other factors such as culture, hierarchy and control systems, communication etc (Hui and Idris, 2009; Johnny and Trisnawati, 2008; Nes, Solberg and Silkoset, 2007) in the field of entrepreneurship development, however, no study has indicated the moderating affect of location most especially on the relationship between individual determinants, external factors and firm characteristics, and firm characteristics. Therefore, this study tends to bridge this gap by investigating the moderating effect of location on the relationship between individual determinants, external factors and firm characteristics, and firm performance. Thus, this paper argues on the crucial importance of location factor in the entrepreneurial and business development. Therefore, the contribution of this study would be very visible in the body of literature in the academic field of entrepreneurship development since this study would become the first study to treat location as a moderating variable in the relationship between entrepreneurial factors (such as individual determinants, external factors and firm characteristics) and firm performance. Accordingly, it would provide unique and important information about vital role of location factor to the policy makers and entrepreneurs/business owners in making decisions about their business and entrepreneurial policies.

\section{Literature Review and Hypotheses Development}

\subsection{Individual Determinant}

The individual determinant is highly rooted in the psychology theory of entrepreneurship. Theorists of this concept have greatly stressed the need for entrepreneur to possess certain entrepreneurial characteristics and apart from those individual characteristics needed to develop entrepreneurship and as such it is imperative to examine the relationship between entrepreneurship development and individual characteristics. The individual characteristic could also be referred to as entrepreneurial characteristics or qualities.

Within the context of this discussion, the individual determinant is being discussed under the perspective of individual characteristics. First, it is important to note that entrepreneurial firms are created by entrepreneurs who posses certain characteristics or personalities that enables him to manage the firm and achieve success. These characteristics are therefore needed to development entrepreneurship. Thus, they formed the vocal point of this discussion. It is crystal clear that studies on the entrepreneur' characteristics are quite abundant, right from the time of Cantillon in 1755, Schumpeters in 1934, Say in 1821, McClelland in 1961 and a host of others. For instance, Olanrewaju (2009) found that the entrepreneurial characteristics are strongly impacting on the entrepreneurial performance of small-scale business. William (2009) in assessing Zimbabwe's entrepreneurship noted that if all the requisite entrepreneurial and managerial skill which is the products of entrepreneurial characteristics is acquired either by the entrepreneurs themselves or by the management for SMEs, they could translate these skills into entrepreneurial performance. Therefore, there is positive relationship between entrepreneurial characteristics and entrepreneurial development.

In line with this, Hashim (2005) noted that entrepreneurial characteristics can influence the type of firm that will be created as well as how it will be managed. Thus, it is important to understand the entrepreneurial characteristics of the entrepreneurs. Several studies have listed the personality characteristics needed to develop entrepreneurship as to include among others; need for achievement and motivation, knowledge, skills, locus of control etc.

Blackman (2003) asserted that individual's characteristics are both attributed to his achievement which also has direct effect to the entrepreneurial firm performance. Colin, Gerard, David and Robert (2005) argued that there is a little point, therefore, in trying to match yourself up to this or that personality type. However, there are some fairly broad characteristics that are generally accepted as being essential if you are going to make a success of the entrepreneurial firm in terms of its performance. Supporting these arguments above, Lawal (2005) and Ogundele (2007) in their studies of indigenous entrepreneurial development found that entrepreneurial 
characteristics which they called personal and psychological factor affect entrepreneurial performance.

Furthermore, being fully aware of the complex nature of individual determinants variable in the academic field of entrepreneurship development in which no one single study can cover at a go, concentrating on a few variables of individual determinants most especially at the individual level would be more better and fruitful instead of lumping everything into one single factor. In this case, bearing in mind their crucial importance and the unique nature upon which the research is being conducted, therefore, this study considered and focused on five crucial variables of individual determinants-mental capacity, motivation and needs, gender, biological make up and attitude, and are in this study called individual determinants.

\subsection{External Determinant}

External determinant has been described in various ways. For instance, it has been seen to mean situations in the environment while other studies viewed it as conditions found in the entrepreneurial environment. Hashim (2005) has also described it as some factors that are capable of dictating the failure and success of the entrepreneurial firms or entrepreneurs himself. The role of external environment has been widely recognized in determining and dictating the performance and the continue existence of the entrepreneurial firms most especially in this critical time. Therefore, there is need to examined the entrepreneurship development with respect to eternal environment.

Several studies have really examined the impact of eternal environment on the entrepreneurial performance. Hence, some body of knowledge exists in this regard. For instance, Hashim (2005) have shown that external factors have a very vital role to play in the determination of the failure or success of the entrepreneurial firms. Another study has asserted that eternal factors can assign boundaries to entrepreneurial firm and entrepreneurs' decisions and on the other hand provide opportunities from the environment. Similarly, Van de Ven (1993) has argued in his work that any study in the field of entrepreneurship which does not regard other variables such as environment should be regarded as insufficient and incomplete. He asserted that research in entrepreneurship should try to look at or view entrepreneurship in a social system perspective which on the other hand gives attention to external environmental conditions and thus, should be considered more appropriate in the explanation of entrepreneurial process. Supporting this, Arowomole (2000) noted that the various factors, forces and actors that make up the external determinant could be problems or opportunities to the entrepreneurs and therefore can effectively determine or influence the entrepreneurial competence and performance of the entrepreneurs. Kuratko and Hodgetts (2004) also shown that external factors could directly or indirectly affect or influence the entrepreneurial decisions thereby also affecting the performance.

However, the external factor in this study only reflects the economic and environmental factors which form part of the dimensionality of external factor. This is line with Kader, Mohamad, Ibrahim (2009) who regard external factor in this perspective. Apart from that, being fully aware of the diverse and dimensionality nature of external factor like that of individual determinants variable in the academic field of entrepreneurship development in which no one single study can cover at a go, dwelling on a few dimensions like economic and environmental becomes more imperative in order to achieve a more better and fruitful result instead of lumping everything into one single factor. Therefore, this study considered and focused on economic and environmental dimension of external factor.

\subsection{Firm Characteristics}

Entrepreneurial firms are being managed by the entrepreneurs. Some of these firms are micro, and while others are small in size. Again, these firms could also be old or new. The management style also varies. The nature of the firm, size of the firm and entrepreneurs' firm knowledge are very crucial. All these form the firm's characteristics and could greatly affect entrepreneurial development. Therefore, it is essential to examine the significant relationship between entrepreneurship development and the entrepreneurial firm's characteristics.

Previous studies have documented the relationship between firm characteristic and entrepreneurship. For instance, Hashim (2005) asserted that firm characteristics seem to play a vital role in determining the performance of the firm and can further determine how well the entrepreneurship have been developed in the country. Wiklunda and Shepherd (2005) using the logic of the configuration approach which he rests on the premise that firms that able to align certain firm attributes with the characteristics of the environment outperform other firms. Hence, those firms that failed to achieve such alignment will eventually be competed out. They further argued that a limited number of configurations of firm and environmental attributes can be used to describe large proportion of high-performing firms. They however, summarized the characteristics of "An entrepreneurial firm as the one that engage in product market, innovation, undertakes some what risky ventures, and is first to come up with "proactive". 
Furthermore, empirical studies have also documented that a positive relationship exist between firm characteristics and entrepreneurial development. Dean, Bülent and Christopher (2000) also reported that size affects a firm's marketing capabilities, attitudes, needs, practices etc which are important determinants firms' performance and success. In line with the above, some studies have examined the relationship between firm size and export performance which they measured by annual sales. The result was found to be fairly straightforward in terms of the effect of the size which was measured by annual sales. Also, Wagner in his study found that firm size measured by annual sales had a positive impact on export sales of the entrepreneurial firm

However, Dean et al., (2000) reported that the connection between firm size which is contained in the firm's characteristics and entrepreneurial performance is a controversial issue in the field of research. They argued that is there is a little in common with the measurement of size whereas the traditional concept is usually indicated by assets, employees, and sales. In support of this argument above, Dean et al., (2000) asserted that other studies that have investigated the use of size to identify gap between group differences produced mixed results. Another study also reported similar thing, summarizing the major findings of five studies based on an extensive review of existing literatures with all the authors concluding that the empirical findings on the relationship between firm size and export intensity (entrepreneurial performance) are all mixed findings.

\subsection{Moderating Effect of Location}

Arguably, the most important factor of entrepreneurship and small business development is the strategical location of the business which could include the nearness to raw material, accessibility to business premises, good rod network, busyness of the area of the business etc. Ilian and Yasuo (2005) defined location as the choice mode of entering business. Thus, the study viewed location in terms of type which could be local or international location. Also, Kala et al., (2010) defined location as choice of where a business is to be located which could be small, medium and large cities or urban or rural locations. this definition is in line with Esteban, Yancy and Christian (2010) referred to location as a choice of locating your business either in the rural or urban centre which is also link with the type of product or service the firm tend to offered. Orloff (2002) economic situation, density of entrepreneur's per capita, composition of local communities etc to location. Therefore, location could be defined as nearness and accessibility of the firm to raw materials, infrastructures, how busy the location is? How accessible the location is to the customers etc?

Location is an indispensible factor that shapes and determines the success or failure of entrepreneurial development and business activities. Thus, it determines the effectiveness of the entrepreneurial and business activities. Previous studies have revealed that firm performance is direct influenced by individual determinants, external factors and firm characteristics (Blackman (2003); Ogundele (2007); Colin et al., (2005); Lawal (2005); Van de ven (1993); Radiah, Mohd and Ab, (2009); Lim (2006) and Dean et al., (2000). However, there have been inconsistent findings in the respective studies, giving room for the introduction of a moderating variable. The inconsistent findings also indicate that some important variables such as location have not been considered in the previous studies. On this note, it is necessary to examine the role of location as a moderator that affect the relationship between individual determinant, external factor and firm characteristics, and firm performance. The essence of this to is to further strengthen the relationship between individual determinant, external factor and firm characteristics, and firm performance and make more directional. In this case, it is expected that location would significantly and positively affect the relationship individual determinant, external factor and firm characteristics, and firm performance in order to make the impact of individual determinant, external factor and firm characteristics on firm performance more effective and significant. With the presence of location, it is assumed that the relationship between individual determinant, external factor and firm characteristics, and firm performance would become more stronger and effective. Hence, location plays a crucial role in the effectiveness of individual determinant, external factor and firm characteristics on firm performance. Therefore, it is argue here that it is not only important for firms, policy makers and entrepreneurs/business owners to consider individual determinants, external factors and firm characteristics but that the effectiveness of these factors on the firm performance depend on the strategic location of the firms which then strengthen the effectiveness.

Kala et al., (2010) has reported that the strategic location of the domestic firms have assisted them in achieve a positive performance. Thus, location has provided domestic firms with strong force to prosper and succeed in their business. They equally noted that location has help firms in the area of sustainability and also imply performance. Accordingly, Orloff (2002) has also provided evidence of effect of location on emergence of entrepreneurs and consequently their performance. The study reported that location play a vital role in entrepreneurship development.

From the on going, one could see that the location is vital factor of entrepreneurship development that when 
aligned with other entrepreneurial factor like individual determinant, external factor and firm characteristics could highly affect the entrepreneurship development and firm performance.

From the above discussions, the following hypotheses are being advanced:

Hypothesis 1: there is a significant relationship between individual determinant and firm performance

Hypothesis 2: there is a significant relationship between external factor and firm performance

Hypothesis 3: there is a significant relationship between firm characteristics and firm performance

Hypothesis 4: location will moderate the relationship between individual determinant and firm performance

Hypothesis 5: location will moderate the relationship between external factor and firm performance

Hypothesis 6: location will moderate the relationship between firm characteristics and firm performance

\subsection{Small Firms Performance}

Trkman, (2009) noted that performance measure is indispensable for entrepreneurial and small firms because it helps them to ascertain the success or failure of the firm and also acts as an indicator to achieve sustainable improvement in entrepreneurial and business activities. Accordingly, Murphy, Trailer and Hill, (1996) argued that "accurate performance measurement is critical to understanding new venture and small business success and failure". However, generally, the concept of performance is very hard to operationalized in the field of research most especially in the field of entrepreneurship and small business. However, one cannot rule out performance when taking about small firms since the performance of the small firms are being measured by their performance.

Researchers in the field of entrepreneurship development have used performance in various perspectives. For instance, (Panigyrakis and Theodoridis, 2007; Murphy et al., 1996) referred to performance as small business performance as well as entrepreneurial performance. However, within the context of this study, we prefer to go with the word "firm performance" in order to align with the context and topic of this present study. Furthermore, small firm performance measurement has been viewed in two major dimensions; the financial and non-financial measures. Thus, researchers are divided on which of these small firm measurement best measure performance.

Several authors have argued that financial measure of small firm performance is the best indicator of performance (Murphy et al., 1996). This may be due to the fact that financial measure such as profitability seems to cover the overall objective of many firms in which small firms are not left out. In deed, financial measure is the primary measure of a firm success and performance. Within the context of small firms and entrepreneurship development, Murphy et al., (1996) argued that financial measure of small firms seems to be common and widely used. In this case, they argued that in the academic field and as well as entrepreneurial field financial indicators seem to gain upper hand when discussing performance. This may be due to; it is easy to use in ranking and judging how a firm is performing in its business operations or activities. Financial measure of performance includes; profit and growth. On the other hand, the non-financial measure of performance which is equally referred to as operational measure is also used in measuring small firm's performance (Murphy et al., 1996, Panigyrakis et al., 2007). For instance, Ittner and Larcker (2003) argued that non-financial performance measure helps managers and owners to ascertain the progress of the business, although, it has been proved to be difficult to manipulate unlike the financial measure. Campbell, (2007) asserted that non-financial measure seems to compliment the financial measure in determining the firm's performance.

The arguments above indicate that one set of firm performance measurement may not be sufficient enough to measure firm performance, therefore, there is need to adopt both financial and non-financial performance measure as suggested by Venkatraman et al., 1986; Panigyrakis et al., 2007). They asserted that it is very important to adopt both financial and non-financial indicators in measuring entrepreneurial performance since it may offer a broader perspective of measuring performance and thus, tend to clarify the relationship between financial and non-financial aspects of entrepreneurial performance under investigation (Panigyrakis et al., 2007; Venkatraman et al., 1986). Accordingly, Murphy et al., (1996) also suggested that researchers in both small firm and entrepreneurship field should always consider multiple dimensions of both financial and non-financial methods of measuring small frms performance in order to arrive at a better measurement. Justifying these further, Dimitratos et al., (2004) argued that due to the arguments about small firm performance measurement which researchers have taken different stands, authors should use and justify at least two different dimensions of firm performance which they argued to be both financial and non-financial measures.

However, in line with the above arguments and considering the uniqueness of the small firms, and coupled with the uniqueness of individual entrepreneur/owners in organizing and managing their firms which is also in line 
with their various objectives, thus, using a single dimension of small firm performance might not give a better result. Hence, this study adopts both financial and non-financial objective measurement of profitability and growth of small firm performance. Muhammad (2009) concurred that these two indicators of financial and non-financial measures seem to be important to entrepreneurial firms as well as small firms. The research framework is presented at the end the end of the article and titled Figure 1-Research Framework

\section{Methodology}

\subsection{Sampling}

The study is a cross-sectional study of questionnaire survey approach with a simple random sampling where the entrepreneurs and owner-managers of small firms in Lagos state were selected as the targeted population of this study. The sample respondents in this study include both the entrepreneurs and owner-managers who did registered with the Lagos state government. The respondents were identified through the Lagos state business directory obtained through the Lagos stage government website. A list of 4225 entrepreneurs and owner-mangers were sorted out from the main lists that comprises of other firms. However, a simple random sampling was used to select 300 entrepreneurs and owner-managers that participated in this study.

A total of 230 completed questionnaires were returned filled, thus, giving $77 \%$ response rate of the total sample. However, the returned completed questionnaires were further reduced to a total sample of 201(67\%) for the fact that some of the returned questionnaires were not properly filled and as such were not used for this study. again, the sample was further reduced to 182 during the treatment of outliers and normality. therefore, the actual sample used in this study for the analyses is 182 which gave a response rate of $61 \%$.

\subsection{Data collection Method}

A pilot study was initially conducted on thirty(30) owner-managers with the locality in order to preliminary assess the existing scale and modify it to suit the context of this present study. Data collection of this study was based on quantitative method of survey questionnaire which was self-administered on the both the owner-managers and entrepreneurs of small firms in three major areas as categorized by the Lagos state government in Lagos state. Some of the respondents first contacted via E-mail and mobile phone numbers to inform them about the survey.

\subsection{Measurement of Variables}

The study uses the primary data collection questionnaire survey technique to achieve it objective. the questionnaire consists of five sections; the profile of the respondents and their business, individual determinant, external factor, firm characteristics, location and firm performance. All variables in study were measured using a five-point Likert scale ranging from $1=$ strongly disagree to $5=$ strongly agree was used to measure the extent to which respondents agree or disagree to each of the statement and questionnaire. Individual Determinant was measure using 37 items of five dimensions, External Determinant was equally measured with eight items adopted and modified from previous studies. The study measured firm characteristics with fifteen items of three dimensions. Items were adopted from previous study (Ensley and Amason, 2000), however, modified for the purpose of this study. Location factor was also measured using eight items that was adopted from the works of Yanfeng et al., (2008) and Ilian et al., (2005) and modified and firm performance was measured with ten items. The items were adopted from the various works of authors such as Francisco and Yi-Wen (2006) and Ogundele (2007), Shradha et al., (2005) and Murphy et al., (1996).

\subsection{Data Analysis Techniques}

The data collected was from the main survey was subjected to data cleansing and data cleaning in order to identified missing value, sample characteristics and meet the assumptions of normality.

A descriptive analysis was used to summarize the respondents' characteristics and their business. Factor analysis was also employed in this regard to help in identify the actual number of factors that actually measured the each constructs as perceived by the respondents. In this case, the component factor analysis with varimax rotation was therefore conducted on all the variables to extract factors from the scales of each construct. Based on the previous works of (Hair, Black, Anderson and Tatham, 2006; Hui et al., 2009) all items loading below 0.50 were not retained and those having a loading factor limit of above 0.50 and Eigenvalue larger than 1 were principles to choose factor (Daud, 2004, Hui et al., 2009). All items were well loaded into their various underlying variable structure of dimensions based on the theoretical framework of this study without prior specification. In the reliability test, variables with less than Cronbach' Alpha coefficient of 0.50 was not included in the analysis. All variables in this study indicated factor loading above recommended limit of Cronbach' Alpha coefficient of 0.50 as reported by Michael, Jackson, Douglas and Wroblewski (2000). Equally, the variables were subjected to 
validity test. The validity of the instrument in this study was measured through Bartlett's Test of Sphericity (Muhammad, 2009). Within this study, the KMO for the construct were all above .6 as indicated as recommended by Chakraborty (2010), Trent, Justen, Anastasios (2009), Nuradli, Hanifah, Shahida, Hairunnizam (2008) and Dahal (2004) meanwhile the diagram below show both the results of the cronbach alpha and KMO. Table 1 at the end of the article shows the results of the reliability and validity.

\subsection{Statistical Analysis}

First, a correlation analysis was employed to first establish the relationship between the independent variables and the dependent variable. The findings of the first three hypotheses are presented below while the table is indicated at the end of the article- Table 2.

1. there is significant relationship between individual determinant and firm performance

$$
(\mathrm{r}=399, \mathrm{p}<0.01)
$$

2. there is significant relationship between external factor and firm performance

$$
(\mathrm{r}=.155, \mathrm{p}<0.05)
$$

3. there is significant relationship between firm characteristics and firm performance

$$
(\mathrm{r}=472, \mathrm{p}<0.01)
$$

After this, a three-step approach techniques of hierarchical multiple regression analysis using SPSS version 17 was then applied in this respect in order test the moderating effect of location on the relationship between the individual determinant, external factor and firm characteristics with firm performance. The results show location only moderates the relationship between the external factor and firm characteristics, and firm performance while location does not moderate the relationship between individual determinant and firm performance. However, it is important to note that the significant R-square change and Significant F change would indicate significant moderating effects by location. Meanwhile the findings of the hypotheses are presented below while tables 3, 4 and 5 at the end of the article show more details of the various results of the moderating hypotheses testing

4. location does not moderate the relationship between individual determinant and firm performance (Sig. $\mathrm{F} \Delta=.317, \mathrm{~F}(3,178)=11.07, \mathrm{p}<0.001)$

5. location moderates relationship between external factor and firm performance (Sig. F $\Delta=.000, \mathrm{~F}(3$, $178)=327.391, \mathrm{p}<0.001$ )

6. location moderate the relationship between firm characteristics and firm performance (Sig. $\mathrm{F} \Delta=.000$, $\mathrm{F}(3,178)=48.704, \mathrm{p}<0.001)$

\section{Findings and Discussion}

This present study proposes that location would moderate the relationship between individual determinant, external factor and firm characteristics, and firm performance. Hence, it provides the indirect test of the various relationships indicated in this study through the applicability of hierarchical regression analysis. In particular, survey data from entrepreneurs and owner-managers in Lagos, Nigeria were used to examine quantitatively whether location moderate the various proposed relationships in this study. Empirical findings presented in this study provide significant insights concerning the moderating effect of location on the relationship between individual determinant, external factor, firm characteristics, and firm performance.

From the results of the hypotheses tests, it was found that location moderates the relationship between external factors and firm characteristics, and firm performance. However, the hypotheses test also indicates that location does not moderate the relationship between individual determinants and firm performance.

First, the result of the first hypothesis indicates that location does not moderate the relationship between individual determinant and firm performance. Although, much evidence is not available to support the not moderating influence of location on the relationship between individual determinant and performance, therefore, this implies that the finding is not consistent with the previous studies. For instance, Orloff (2002) has asserted that location play a very vital role in the development of entrepreneurship which also include the small of firms. This was in line with the role location played in the emergence of entrepreneurs in Canada.

This result suggests that the even though entrepreneurs and owner-managers do not give consideration to location factor, they can still achieve greater performance through their individual determinants (entrepreneurial traits). However, the insignificant of location within this context, does not down play the role of location factor in the success of entrepreneurship and small development. Giving another setting, different environment and also different set of data, location could produce a significant result. Additionally, the cause of this insignificant of 
location in this relationship might be due to overlap of other variables in the study. We must understand that common strategic knowledge has demonstrated that if a firm is strategically located; such firm has a better chance to achieve its goals than a firm that is not located strategically. Therefore, individual determinant of entrepreneurs and owner-managers should be aligned with their business location. This would produce a positive result with respective to their business success and performance.

Secondly, the findings from the hypotheses testing further indicated that location strongly moderate the relationship between external factor and firm performance. The results suggest that location strengthens the relationship between firm characteristics and firm performance. It further implies that firms that are strategically located are more likely to achieve a better performance than those that are not strategically located.

This again re-echoed the influence of location in the development of entrepreneurship and small business as asserted by Orloff (2002). This result again suggests that entrepreneurs and owner-managers must blind their external factor and location since the incorporation of location into the relationship between external factor and firm performance produce a meaningful result. Although, as indicated earlier that much of the burden with regard to external factor depend on government, therefore, government in thinking on how to solve the problem of external factor must merge integrates location into external factor so as to produce a useful result. External factor is very crucial in entrepreneurial development but would yield better results if it is merged with location. Location should be seen as a separate factor that should be merged with the external factor.

Thirdly, the testing of this hypothesis produced a significant result. The result indicates that location does moderate the relationship between firm characteristics and firm performance. Thus, the effect of location was felt in their relationship. Including location factor has further strengthened the relationship between firm characteristics and firm performance.

Although, one hopes that location should influence their relationship, however, the present result has provided empirical evidence to that effect. This result suggests that location is very important factor in the relationship between firm characteristics and firm performance. The nature of this significant relationship suggests that an urgent consideration should be given to location factor. Therefore, this result suggests that both government policy makers, and entrepreneurs and owner-managers should think on how to urgently utilize location factor in the development of entrepreneurship and small business. Doing this could help and assist the stakeholders of entrepreneurship and small business development achieves a better result or performance.

The findings of the moderating effect of location on the relationship between individual determinants, external factors and firm characteristics, and firm performance no doubt bears interesting contributions. First, to the study, the contribution of this study would be very visible in the body of literature in the academic field of entrepreneurship development since this study would become the first study to investigate location as a moderating variable in the relationship between entrepreneurial factors (such as individual determinants, external factors and firm characteristics) and firm performance. Accordingly, it would provide unique and important information about vital role of location factor for most SMES firms, policy makers and entrepreneurs/business owners in making decisions about how and manner in which they can strategically locate their firms for effective firm performance.

\section{Conclusion}

this study adopts and incorporates model from Ogundele (2007) to develop a broader dimensionality and better framework for developing entrepreneurship and small business particularly in Nigeria and as such gave a serious considerations and attention to individual determinant, external factor, firm characteristics and location which have been in the literatures to have serious influence in the development of entrepreneurship and small business. Therefore, within the context of the hypotheses tested in this study and the findings obtained, the following conclusions are therefore made;

1. The results confirmed the hypotheses that location does not play a vital role in the moderating of relationship between the individual determinant and firm performance.

2. the study also confirmed that the influence of location is important in the relationship between the external factor and firm characteristics, and firm performance

3. However, on the overall, location factor has demonstrated to be very significant in predicting of small firm performance as well as in the development of entrepreneurship.

\subsection{Limitation and Suggestion for Future Study}

Obviously, there is no research with its limitations. The non significant result indicated in the relationship 
between individual determinant and firm performance as moderated by location could limit the generability of finding of this result. In any research work, the applicability and generability of research findings seems very important. Sekaran et al., (2000) argued that the more a research findings is generalisable then the greater the usefulness and as well as its value. To generalize research findings, certain conditions are very imperative. First, a large sample is required; secondly, the same research if done in a different setting should be able to produce the same result. Again, the other research methods should be applied in order to see if the same result could be obtained. Based on this, the findings of this research is limited in these respects. this therefore suggest for a future research to be undertaking, there is a need for further studies to be carryout in order establish the generalisibility of the above results in a different setting and with a different sample data.

\section{Appendix A: Measurements}

Individual Determinants (adopted from Francisco et al., (2006; Ogundele, 2000)

(5-point Likert scale; 1 = strongly disagree; $5=$ strongly agree)

37 items were used to collect data from the respondents.

Variables; five variables; attitude (5 items); biological make up (5 items); motivation and needs (10 items); mental capacity (9 items) and gender (5 items)

1. My family business background has the influence on how I manage my business

2. My I gathered my business experience from my childhood experience

3. My friends influences my business performance

4. My relatives influences my business performance

5. My early family exposure to business activities influence my business performance

1. Availability of government assistance like Tax incentive

2. Availability of individual support

3. Availability of moral support

4. Advisory/technical assistance

5. Availability of facility support

6. Need for financial reward to making money

7. Need for achievements

8. Desire to get things done by all cause

9. Desire to create employment for family members

10. Desire to be industrious

1. I am capable of handling business issues that contribute to my business performance

2. I have ability to resolve business issues that will contribute to my business performance

3. I am disturbed by situations that could affect my business performance.

4. I am distract by family matters that could affect my business performance

5. I have a stable mind to conducted my business activities in order to achieve success

6. I have mental alertness to recognize profitable business opportunities

7. I have Sound decision and judgment towards achieving business success.

8. I have maturity in handling complex matters toward achieving business success

9. I have self ability, control and management towards which contribute to my business performance

1. I have positive feelings towards tasks that gratify me to succeed in my business

2. I have thinking towards planning my business to succeed

3. I have positive feelings to response immediately to employees' needs that contribute to my business performance 
4. I have positive feelings to response to employees/customers complaints

5. I recognize and praise for my business performance

6. I look for good life all the time

7. I give priority to my business activities

8. I often give attention to my business environment

1. My gender is more into entrepreneurial activities than the other gender

2. The business represented by entrepreneurs of my gender are more successful than other opposite gender

3. My gender business management style is more effective in achieving business performance than the opposite gender

4. My gender is more effective in achieving business success than other opposite gender

5. My gender business experience is more effective in achieving business success than other gender External factor (adopted from (Kaderet al., 2009)

(5-point Likert scale; 1 = strongly disagree; $5=$ strongly agree)

1. Infrastructure and facilities contribute to my business performance

2. The domestic economic conditions contribute to my business performance

3. Government policy contributes to my business performance

4. The availability of raw materials

5. Supply contributes to my business performance

6. Power supply contribute to my performance

7. Access to capital/loans/funds contributes to my performance

8. The current economic condition in the country contribute to my business performance

9. The current business environment in the country influence my business performance

Firm Characteristics (adopted from Ensley and Amason, 2000)

(5-point Likertscale; 1 = strongly disagree; $5=$ strongly agree)

Variables: Nature of firm, firm size and firm knowledge

1. I consider my product/service is very unique in the market.

2. I consider my product/service is big well accepted by the customers due to the quality

3. I found my product/service strength is due to the pricing

1. I have full control of my employees

2. I have full control of my finance

3. I have full control of my production process

4. I am flexible in decision makings

5. My workforce is less strengthened

1. I have adequate knowledge of my customers

2. I have adequate knowledge of my employees

3. I have adequate knowledge of my suppliers

4. I have adequate knowledge of my creditors/debtors

5. I have adequate knowledge of my distributors

6. I have adequate knowledge of my firm operations

7. I have adequate knowledge of the market

Location (Adopted from Yanfeng et al., 2008; Ilian et al., 2005)

(5-point Likert scale; 1 = strongly disagree; $5=$ strongly agree) 
1. My firm is located in the busy area

2. Customers cannot access to my business premises because of non free flow of traffic to my business place

3. My business location is not suitable in such a way that it hinders my firm to perform at the level I wanted

4. The electricity supply is not constant to aid my business performance

5. The good road network is considered poor

6. The location is remote from technological reach

7. The availability and access to information to my business are poor

8. My firm is located near to the source of raw materials/suppliers

Firm Performance (adopted from as Francisco et al., (2006) and Ogundele (2000), Shradha et al., (2005) and Murphy et al., (1996).

(5-point Likert scale; 1 = strongly disagree; $5=$ strongly agree)

1. I recorded a commendable nature of growth in sales since in the last 2 years

2. I recorded increment in marketshare

3. Growth in profit in last 3 years

4. Commendable profit after tax on sales

5. My over all business performance and success is commendable

6. I am quite satisfied with the sufficient level of income from my business and my business size

7. I ensure that my business income is sufficient for me and my family

8. I am concern with the quality of life for myself and for my family

9. Profit is not my top priority

10. I am more concern about the sustainability of my business and its growth

\section{References}

Arowomole, K. A. (2000). Modern Business Management(Theory and Practice). 1st Edition. Sango-Ota, Ogun State: Ade-Oluyinka Commercial Press

Blackman, A. J. (2004). Entrepreneurs: Interralationship between their Characteristics, Nalues, Expectations Management Practices and SME Performance.

Chakraborty, S. (2010). A Study of Select Discount Store Retail in Hyderabad for the Purpose of Identifying Factors in Regards to Shopping Motives, Store Attributes, Shopping Outcomes and Perceived Shopping Cost. International Journal of Global Business, 3(1): 1-19.

Chandler, G., \& Hanks, S. (1994). Founder Competence, the Environment, and Venture Performance. Entrepreneurship Theory Practice, 18(3): 77-89.

Colin, B., Gerard, B., David, M., \& Robert, B. (2005). Enterprises Development: The Challenges of Starting, Growing and selling Businesses. London: Thomson Learning Publisher.

Cooper, A. C. (1993). Challenges in Predicting New Firm Performance. Journal Business Venturing, 8 (3): 241-253.

Dahal, H. (2004). Factor Analysis for Soil Test Data: A Methodological Approach in Environment Friendly Soil Fertility Management. Ministry of Agriculture and Cooperatives .

Daud, N. (2004). Human Resources Management Practices and Firm Performance: A Case Study of Manufacturing Firms in Malaysia. Malaysia: National University Malaysia.

Dean, D. L., \& Bülent Mengüç, C. P. (2000). Revisiting Firm Characteristics, Strategy, and Export Performance Relationship: A Survey of the Literature and an Investigation of New Zealand Small Manufacturing Firms. Industrial Marketing Management, 29: 461-477.

Ensley, M.D., \& Amason, A.C. (2000). Entrepreneurial Team Heterogeneity and the Moderating Effects of Environmental Volatility and Team Tenure on New Venture Performance. Working Paper. 
Esteban, L., Yancy, V., \& Christian, S. (2010). Location decisions of knowledge-based entrepreneurs: Why some Catalan KISAs choose to be rural? Technovation.

Francisco, L., \& Yi-Wen, C. (2006). Testing The Entrepreneurial Intention Model On A Two-Country Sample. Departament d'Economia de l'Empresa.

Greening, D. W., Barringer, B. R., \& Macy, G. (1996). A Qualitative Study Of Managerial Challenges Facing Small Business Geographic Expansion. Journal of Business Venturing, 11: 233-256. http://dx.doi.org/10.1016/0883-9026(95)00108-5

Hashim, K. M. (2005). Small and Medium-Sized enterprises in Malaysia-Role in Isuues. Sintok: UUM Press.

Henri, J.-F. (2006). Organizational culture and performance measurement systems. Accounting, Organizations and Society, 31: 77-103.

Hui, C. B., \& Idris, K. (2009, January-June). Absortive Capacity, Organisational Culture and Innovation at MSC Companies Malaysia. Skill Management, 44(1): 1-21.

Ilian, P. S., \& Yasuo, H. (2005). Influence of location factors on establishment and ownership of foreign investments: The case of the Japanese manufacturing firms in Europe. International Business Review, 14: $577-598$.

Johnny, J., \& Trisnawati, S. (2008). The Moderating Effects of Hierarchy and Control Systems on the Relationship Between Budgetary. The International Journal of Accounting, 43: 268-292.

Kader, R. A., Mohamad, M. R., \& Ibrahim, A. A. (2009). Success Factors for Small Rural Entrepreneurs under the One-District-One-Industry Programme in Malaysia. Contemporary Management Research, 5(2): 147-162.

Kala, S. S., \& Guanghua, W. (2010). Firm location choice in cities: Evidence from China, India, and Brazil. China Economic Review, 21,113-122.

Kisfalvi, V. (2002). The Entrepreneur's Character, Life Issues, and Strategy Making a field study. Journal of Business Venturing, 17: 489-518.

Kuratko, D. K., \& Hodgetts, R. M. (2004). Entrepreneurship: Theory, Process \& Practice. 6th Edition. United States of American: Thomson South-Western.

Lawal, A. A. (2005). Management practices and Organisational Effectiveness in nigeria Small and Medium Enterprises(SMEs). Akoka, Lagos: University of Lagos.

Michael, C. A., Jackson, D. N., \& Wroblewski, V. R. (2000). The Impact of Faking on Employment Tests: Does Forced Choice Offer a Solution? Human Performance, 13(4): 371-388.

Muhammad, M. A. (2009). The Combine Effect of Market Orietation and Owner/Manager's Innovation and Business Performance of Small and medium Sized Manufacturing Firms in Pakistan. Sintok, Kedah, Malaysia: $\mathrm{PhD}$ Thesis, UUM.

Murphy, G. B., Trailer, J. W., \& Hill, R. C. (1996). Measuring Research Performance in Entrepreneurship. Journal of Business Research, 36:15-23. http://dx.doi.org/10.1016/0148-2963(95)00159-X

Nes, E. B., Solberg, C. A., \& Silkoset, R. (2007). The Impact Of National Culture And Communication On Exporter-Distributor Relations And On Export Performance. International Business Review, 16: 405-424.

Ogundele, O. J. (2007). Introduction to Entrepreneurship Development, Corporate Government and Small Business Management. 1st Edition. Lagos: Molofin Nominees.

Okpara, J. O., \& Wynn, P. (2007). Determinants of Small Business Growth Constraints in a Sub-Saharan African Economy. SAM Advanced Management Journal.

Olanrewaju, O. (2009). Entrepreneurship and Performance of Small-Scale Enterprises in Nigeria. Nigerian Economic Society Journal, 47(2).

Orloff, A. (2002). Social Venture Partners Calgary: Emergence and Early Stages. Canadian Centre for Social Entrepreneurship.

Pavlos, D., Spyros, L., \& Sara, C. (2004). The Relationship Between Entrepreneurship And International Performance: The Importance Of Domestic Environment. International Business Review, 13:19-41.

Pelham, A. M. (1999). Influence of Environment, Strategy, and Market Orientation on Performance in Small Manufacturing Firms. Journal of Business Research, 45: 33-46.

Rajesh. (2006, February 28). Entrepreneurship Development: Concept and Context. Indian, Indian, Indian. 
[Online] Available: http://dobato.blogspot.com/2006/02/entrepreneurship-development-concept.html (January 8 , 2010)

Rebecca, E. O. (2009). Entrepreneurial Competencies: The Missing Links to Successful Entrepreneurship in Nigeria. International Business Research, 2(2): 62-71.

Robert, J. T., \& Sammi, K. L. (2007). Measuring Chinese Entrepreneurial Motivation Personality and Environmental Influences. International Journal of Entrepreneurial Behaviour \& Research, 13(4): 200-221. http://dx.doi.org/10.1108/13552550710759997

Sekaran, U., Robert, Y. C., \& Brain, L. D. (2001). Applied Business Research. 1st edition. Australia: John Wiley \& Sons Australian Ltd.

Shradha, S., Mukherjee, S., \& Sharan, R. (2005). Structural Interventions For Favourable Sociocultural Influences On India Entrepreneurs. Indian.

Trent, D. B.; Justen, P. O'Connor \& Anastasios, N. B. (2008). Instrumentation and motivations for organised cycling: the development of the Cyclist Motivation Instrument (CMI). Journal of Sports Science and Medicine, 8: 211-218.

Van De Van, A. (1993). The Development of Infrastructure for Entrepreneurship: Key Dimensions and Research Implications. Journal of Business venturing, 8: 211-230.

Ventkataraman, N., \& Ramanujam, V. (1986). Measurement of Business Performance in Strategy Research: A Comparison of approaches. Academy of Management Review, 801-814.

Wiklunda, J., \& Shepherd, D. (2005). Entrepreneurial Orientation And Small Business Performance: A Configurational Approach. Journal of Business Venturing, 20:71-91

William, M. (2009, April Thursday). Managerial Skills for Small to Medium Enterprises and the Informal Sector to enhance development and Business Growth. Zimbabuwe, Zimbabuwe.

Yanfeng, Z., \& Si, C. (2008). The Impacts of External Factors on the Growth of Chinese Entrepreneurial Enterprises an Empirical Study. Journal of Small Business and Enterprises Development, 15 (4): 689-703. http://dx.doi.org/10.1108/14626000810917807

Yong-Hui, L., Jing-Wen, H., \& Ming-Tien, T. (2009). Entrepreneurial Orientation And Firm Performance: The Role Of Knowledge Creation Process. Industrial Marketing Management, 38: 440-449.

Table 1. Reliability and Validity scores by the construct used in this study ( $\mathrm{N}=182)$

\begin{tabular}{|c|c|c|l|}
\hline Variables & Item No & Cronbach's Alpha Scores & KMO \\
\hline Individual Determinant & 27 & .840 & .721 \\
\hline External Factor & 8 & .853 & .834 \\
\hline Firm Characteristics & 13 & .857 & .829 \\
\hline Location & 7 & .682 & .631 \\
\hline Firm performance & 10 & .820 & .837 \\
\hline
\end{tabular}

Table 2. Correlation analysis among independent and dependent variables

\begin{tabular}{|l|l|l|c|c|}
\hline Variables & Indv & Extfact & Fimch & Perf \\
\hline Individual determinant & 1 & & & \\
\hline External factor & $.229^{* *}$ & 1 & & \\
\hline Firm characteristics & $.621^{* *}$ & $.311^{* *}$ & 1 & \\
\hline Location & $.198^{* *}$ & $.170^{*}$ & $.234^{* *}$ & \\
\hline Performance & $.399^{* *}$ & $.155^{*}$ & $.472^{* *}$ & 1 \\
\hline
\end{tabular}

$* \mathrm{p}<0.05 ; * * \mathrm{P}<0.01, \mathrm{n}=182$ 
Table 3. Hierarchical regression result for moderating effect of location on the relationship between individual determinant and firm performance

\begin{tabular}{|l|c|c|c|}
\hline Predictors & $\begin{array}{c}\text { Model 1 } \\
\text { (Step 1) }\end{array}$ & $\begin{array}{l}\text { Model 2 } \\
\text { (Step 2) }\end{array}$ & $\begin{array}{c}\text { Model 3 } \\
\text { (Step 3) }\end{array}$ \\
\hline Individual Determinant (beta) & .385 & .337 & .549 \\
\hline Location (beta) & & .066 & .372 \\
\hline Interactive Terms & & & \\
\hline INDV*LOC & & & .376 \\
\hline $\mathrm{R}^{2}$ & 148 & .152 & .157 \\
\hline Adjusted $\mathrm{R}^{2}$ & .143 & .143 & .143 \\
\hline $\mathrm{R}^{2} \Delta$ & .148 & .004 & .005 \\
\hline $\mathrm{F} \Delta$ & 31.306 & .917 & 1.007 \\
\hline Sig. F & .000 & .340 & $.317^{\mathrm{NS}}$ \\
\hline
\end{tabular}

$* \mathrm{P}<0.10, * *<0.05, * * * \mathrm{p}<0.001$, Sig $=$ Significant, Not Sg. $=$ Not Significant, $\mathrm{n}=182$

Table 4. Hierarchical regression result for moderating effect of location on the relationship between external factor and firm performance

\begin{tabular}{|l|l|l|l|}
\hline Predictors & $\begin{array}{l}\text { Model 1 } \\
\text { (Step 1) }\end{array}$ & $\begin{array}{l}\text { Model 2 } \\
\text { (Step 2) }\end{array}$ & $\begin{array}{l}\text { Model 3 } \\
\text { (Step 3) }\end{array}$ \\
\hline $\begin{array}{l}\text { External Factor (beta) } \\
\text { Location (beta) }\end{array}$ & .170 & .159 & -.942 \\
Interactive Terms & .095 & .029 & \\
EXT*LOC & 1.429 & & \\
$\mathrm{R}^{2}$ & .029 & .038 & .847 \\
Adjusted R $^{2}$ & .024 & .027 & .844 \\
$\mathrm{R}^{2} \Delta$ & .029 & .009 & .808 \\
$\mathrm{~F} \Delta$ & 5.378 & 1.660 & 938.164 \\
Sig. F & .022 & .199 & $.000 * * *$ \\
\hline
\end{tabular}

$* \mathrm{P}<0.10, * *<0.05, * * * \mathrm{p}<0.001$, Sig $=$ Significant, Not Sg. $=$ Not Significant, $\mathrm{n}=182$

Table 5. Hierarchical regression result for moderating effect of location on the relationship between firm characteristics and firm performance

\begin{tabular}{|l|c|c|l|}
\hline Predictors & $\begin{array}{l}\text { Model 1 } \\
\text { (Step 1) }\end{array}$ & $\begin{array}{l}\text { Model 2 } \\
\text { (Step 2) }\end{array}$ & $\begin{array}{l}\text { Model 3 } \\
\text { (Step 3) }\end{array}$ \\
\hline Firm Characteristics(beta) & .472 & .466 & .007 \\
Location (beta) & .036 & -.004 & \\
Interactive Terms & & & \\
FIMCH*LOC & .667 & & \\
$\mathrm{R}^{2}$ & .223 & .224 & .451 \\
Adjusted R & .218 & .215 & .441 \\
$\mathrm{R}^{2} \Delta$ & .223 & .001 & .227 \\
F $\Delta$ & 51.516 & .287 & 73.590 \\
Sig. F $\Delta$ & .000 & .593 & $.000^{* * *}$ \\
\hline
\end{tabular}

$* \mathrm{P}<0.10,{ }^{* *}<0.05,{ }^{* * *} \mathrm{p}<0.001$, Sig $=$ Significant, Not Sg. $=$ Not Significant, $\mathrm{n}=182$ 
Individual Determinant

- Attitude

- Motivation \& Needs

- Mental Capacity

- Biological Make Up

- Gender

\section{External Factors}

- Economic and environmental

- Political

)

